\title{
Minna Haapio
}

\section{Murder on Music Row - Kuka murhasi kantrin?}

\author{
Ol' Hank wouldn't have a chance \\ On today's radio \\ Since they committed murder \\ Down on Music Row
}

Vuonna 2001 Alan Jackson ja George Strait voittivat Country \& Western -musiikin (C\&W, kantri) murroksesta kertovalla kappaleellaan Murder on Music Row (Shell \& Cordle 1999) kantrimusiikin keskusjärjestön CMA:n myöntämän Song of the Year -palkinnon. Ammattisanoittajien tekstittämässä, uutta ja vanhaa yhdistelevää uustraditionaalista suuntausta edustavassa ja suuren suosion saavuttaneessa laulussa murehditaan ironisesti kantrin nykytilaa: genre on kuollut ja tilalla on valepukuinen pop ja rock. Sanoissa syytetään Nashvillessä sijaitsevia jättimäisiä levy-yhtiöitä (Music Row) ja mainoksista tulonsa saavaa radiota murhasta. Jopa sellaisten legendaaristen esiintyjien kuten George Jones on vaikea löytää julkaisukanavia:

Why they even tell the Possum

To pack up and go back home

There's been an awful murder

Down on music row

Nykykantrin megatähtien esittämään kappaleeseen kulminoituu tutkimuskohteenani olevassa yhdysvaltalaisessa C\&W:ssä jo kauan jatkunut, 1990-luvulla Yhdysvaltojen eteläosissa asuessani huippunsa saavuttanut keskustelu musiikin aitoudesta, tuotteistamisesta ja siitä, miksi perinteinen kantri ei kelpaa medialle, vaikka se kelpaisi yleisölle. Tämän tiedotusvälineiden ja Internetin lisäksi myös itse musiikissa ja sanoituksissa (mm. Willie Nelson, outlaw-liike) käydyn ainutlaatuisen keskustelun valossa on hyvä pohtia genren merkitystä populaarimusiikissa. Saman genre-nimikkeen alla tuotettu erilainen musiikki ja sillä yleisöstä kilpaileminen luovat musiikkiteollisuudessa moninaisia ristiriitoja, joita seuraavassa tarkastellaan kantrin kautta. Kuka määrittää 
genren? Löytyvätkö "syylliset" radiosta, levy-yhtiöistä vai levylautasten ääreltä? Onko genren rajoja mahdollista rikkoa ja mikä on sen hinta? Saavutetaanko jotain? Kuka tappoi C\&W:n ja onko se ylipäätään kuollut? Olen perehtynyt aiheeseen sekä kantrin tekstejä käsittelevän tutkimustyöni kautta että Yhdysvaltain eteläosissa asumalla.

\section{C\&W ja genre}

For the steel guitars no longer cry

And the fiddles barely play

But drums and rock ' $n$ ' roll guitars

Are mixed up in your face

Sana genre on alunperin latinaa ja tarkoittaa luokkaa tai lajia. Erityisesti kirjallisuudessa ja kielitieteessä se viittaa käytännössä tietynlaiseen tekstiin tai tekstiryhmään. Tekstillä taas tarkoitetaan joko kirjoitettua tai puhuttua (laulettua) tekstiä, tai kokonaista diskurssia: tekstiryhmiä, ilmauksia ja niiden sosiaalista kenttää. Tämän vuoksi genreä on kutsuttu myös diskurssikäytännöksi (ks. esim. Kalliokoski 1996). Walserin (1993: 29) mukaan diskurssikäytännöstä keskusteleminen muokkaa ja vahvistaa sitä; genre on lukijoiden ja kuulijoiden odotushorisontti sekä kirjoittajien ja säveltäjien töiden lähtökohta. Näiden tulkintojen pohjalta musiikin diskurssikäytäntö muodostuu siis sävelestä, mahdollisesta sanoituksesta, soittimista, tulkinnasta, tyylistä, äänimaailmoista ja muista musiikillisista ominaisuuksista. Musiikin diskurssikäytäntöjä ovat mm. klassinen musiikki, popmusiikki, jazzmusiikki ja niiden erilaiset alalajit, kuten fuusiojazz. Tekstillä puolestaan viitataan jatkossa yksittäiseen genrensä edustajaan, ellei toisin mainita. Täten esimerkiksi yksi kappale sävelineen, sanoineen ja tulkintoineen on yksi teksti, joka puolestaan on osa genreä, diskurssikäytäntöä.

C\&W määritellään ja mielletään yleensä amerikkalaiseksi 1920-luvulla kaupallistuneeksi konservatiiviseksi sanoituspainotteiseksi populaarimusiikin lajiksi, jossa lauletaan erilaisista ihmiskohtaloista syntymää, kuolemaa ja alkoholismia myöten, ja jossa taustalla soivat $\mathrm{mm}$. havaijilainen/steel kitara, viulut ja dobro kantrille tyypilliseen twang-tyyliin. Kantri on myös vahvasti tanssimusiikkia. Määritelmiä on useita, mikä lienee kaikille genreille ominaista, varsinkin jos ne jakautuvat useampaan alalajiin. Kantrin lyriikoiden omintakeisuus perustuu amerikkalaiseen keski- tai työväenluokkaiseen näkökulmaan ja ideologiaan ja musiikin 4+4+4+4 (4) -poljento (tarkka analyysi löytyy esim. Neal 1998: 323-333) poikkeaa muista genreistä. Sanoitusten tärkeys ja tyyli sekä kitaralla säestäminen ovat kappaleita yhdistäviä tekijöitä. Menneinä aikoina nasaalisen, matalan tai muuten erikoisen ääni-instrumentin lisäksi mainittiin usein myös ääntämistavasta läpikuultava lokaalisuus, Yhdysvaltojen eteläosat. Nykyään paikallisuus ei ole itseisarvo, mutta $\mathrm{C} \& \mathrm{~W}$-teollisuus on edelleen keskitty- 
nyt Tennesseen Nashvilleen. Tunnettuja kantriartisteja ovat Jacksonin ja Straitin ohella mm. Tim McGraw, Patty Loveless ja Trisha Yearwood.

Genre voidaan yleensä tunnistaa helposti, mutta sen määritteleminen on huomattavasti vaikeampaa. Chandlerin (1997) mukaan perinteiset genren määritelmät huomioivat mm. genreen kuuluviksi oletettujen tekstien sisällön (teemat, ympäristöt) ja muodon (rakenne, tyyli). Kaikki genrelle tyypilliset ominaisuudet löytyvät silti harvoin jos koskaan yksittäisestä tekstistä (Chandler 1997), eivätkä tietyt ominaisuudet ole tyypillisiä vain yhdelle genrelle: niiden yhdistely, painotus ja tehtävät ovat erottavia tekijöitä (Neale 1980: 22-23). Pelkkä aihe ei siis riitä esimerkiksi western-elokuvan määritelmäksi, mutta voidaan melko varmasti sanoa kyseessä olevan lännenelokuvan, jos siinä on karjapaimenia tai intiaaneja, preeriaa, hevosia, ampumista ja 1800luvun amerikkalaisia pikkukaupunkeja. Yksittäiset tekstit voivatkin joskus vaeltaa uusina sovituksina genreistä toisiin ja mukautua niihin. Tästä hyvä esimerkki on kantriartisti Garth Brooksin kappale If Tomorrow Never Comes poplaulaja Ronan Keatingin esittämänä. Mikäli yksittäisen teoksen ideologia tai tyyli kuitenkin poikkeaa kohdegenrestä liikaa, vastaanottajat eivät välttämättä kykene ymmärtämään teosta tai hyväksymään sitä. Tekstejä voidaan tulkita ja tuottaa monista lähtökohdista. Toiset tekstit ovat tunnusmerkillisempiä genrensä edustajia kuin toiset - ne ovat genrejensä prototyyppejä.

Genren moninaisuuden sanelee yhteiskunnan monipuolisuus. C\&W ammentaa erityisen moniulotteisesta ympäristöstä, onhan se syntynyt Yhdysvaltain uudisasukkaiden ja orjien afrikkalaisista, irlantilaisista, saksalaisista ja brittiläisistä juurista ja rajaseutujen vapaudesta sekä itsenäisyydestä. Bluesista ja folkista eriytyneenä se kertoo aikansa yhteiskunnan ilmiöistä pääasiassa valkoisen, keski- ja työväenluokan heteronormatiivisesta näkökulmasta (Veith 2001; MRI 2000). Suurin yleisö löytyy Yhdysvaltojen etelä- ja keskiosista. Voisi luulla, että uutta ja entistä yhdistelevä genre pysyisi elinvoimaisena ja uudistumiskykyisenä, mutta Murder on the Music Rown kaltaiset kappaleet ja kantrista käyty keskustelu antavat ymmärtää toisin. Kantria syytetään mm. yksitoikkoisuudesta, itsensä toistamisesta, perinteiden pettämisestä, tuotteistumisesta ja naivismista ja ennen kaikkea siitä, että C\&W-nimikkeen alla tarjotaan musiikkia, joka muistuttaa enemmän iskelmää kuin sitä, mitä on totuttu pitämään kantrina. Hank Williamsia ja Merle Haggardia ei soiteta radiossa. Viulujen sijasta soivat torvet ja tekniikka. Genre ei enää olekaan takuu tutusta ja turvallisesta tuotteesta. 


\section{Kenelle genret soivat?}

They thought no one would miss it

Once it was dead and gone

They said no one would buy them ol'

Drinkin' and cheatin' songs ("Oh, but I still buy 'em”)

Hodge \& Kress (1988: 7) määrittelevät genren tekstien tyypilliseksi muodoksi, joka linkittää tietyt tuottajat, kuluttajat, aiheet, median, tavan ja paikan. Genret eivät kuitenkaan ole tarkkoja järjestelmiä, jotka koostuvat tietyistä lukumäärältään vakioista valmiiksi listatuista osista (Gledhill 1985: 64). Ne voivat olla myös päällekkäisiä tai yhdisteltyjä sekagenrejä, kuten Cledus T. Juddin huumori-kantri, jossa parodioidaan genreä itseään. Genreen luodaan uutta koko ajan. Kumulatiivisen luonteensa takia genren korpus laajenee jatkuvasti ja tästä syystä se muuttuu (Chandler 1997). Järjestelmän sijaan genre on jatkuva neuvottelu- ja muutosprosessi (ks. esim. Walser 1993). Muutoksessa genre yleensä säilyttää ne ominaispiirteensä, joista se tunnistetaan, mutta voi myös uusiutua. Syntyy uusia alakategorioita, jopa uusia genrejä ja taustalla vaikuttaneet genret pysähtyvät, eivätkä enää laajene. Tudorin (1974: 225-226) käsityksen mukaan genrellä on kolme piirrettä:

A) uusien asioiden lisääminen olemassa olevaan korpukseen entisten vähempiarvoisten poistamisen sijasta tekee genrestä kumulatiivisen

B) koska uudet asiat liittyvät aina jollain tavalla jo oleviin, genre on myös konservatiivinen

C) alalajien synty edellyttää eriytymistä

Hodgen ja Kressin (1988: 7) mukaan genre voi olla olemassa vain jos sosiaalinen ryhmä esittää sille normit ja noudattaa niitä. Genre ei koskaan synny tyhjiöön ja sen muotoutumiseen vaikuttavat aina myös sosiaaliset syyt. Täten genre on myös arvojen ja ideologioiden kenttä. Uudisasukkaiden musiikista polveutuva C\&W ja sen kuulijakunta ovat muuttuneet yhteiskunnan ja viihdeteollisuuden mukana, vaikka perinteistä pidetäänkin sitkeästi kiinni. Kantrilla on aina ollut monia alalajeja, mutta vain kaksi pääyleisöä (Flippo 2002b). Molempien yleisöjen ideologiat rakentuvat samalle amerikkalaiselle konservatiiviselle pohjalle, mutta poikkeavat toisistaan ainakin sukupolven arvomaailman verran. Nämä yleisöt jakautuivat 1990-luvulla yhä selvemmin omiin leireihinsä. Flippo (2002c) määrittelee lajit seuraavasti: punainen, patrioottinen kantri on hihatonta ja tatuoitua, raakaa ja kovaäänistä, eikä sitä soiteta radiossa, kun taas sininen, pehmeämpi kantri on kauluksellista ja säädyllistä, eikä herätä nukkuvaa vauvaakaan. Peterson (1997: 151-154) nimittää näitä suuntauksia hard core ja soft shell -kantriksi. Hard core -yleisön (Flippon punainen) juuret ovat usein maaseudulla ja he pitävät suoraviivaisesta, yksilön oikeuksia puoltavasta musiikista, mutteivät karsasta pieniä pop-vivahteitakaan. Vanhan kantrin lisäksi kuunnellaan mm. 
sellaisia uustraditionalisteja ja tarinoitsijoita kuin Randy Travis. Soft shell -yleisöä (sininen) edustaa moderni, usein kaupungistunut kuuntelija, joka pitää puristisesta retro-soundista, mutta myös uusista kokeiluista. Tanssittavuus ja idolisointi ovat jopa sanoja tärkeämpiä, soittimet sähköisiä. Tätä tyyliä edustaa mm. Faith Hill.

Genren kahtiajakoon ja tyylisuuntien eriytymiseen niin kantrissa kuin muussakin musiikissa on olemassa useita syitä. Yksi tärkeimmistä on uusi musiikintekijäpolvi ja sen uudet arvot ja toimintatavat. Useimmat kantrin suurnimistä ovat jo pitkälti yli eläkeiän. Esimerkiksi vastikään edesmennyt Johnny Cash syntyi vuonna 1932 ja vaikutti musiikkipiireissä kuolemaansa saakka. Myös uusi teknologia ja yhteiskunnan muutoksen myötä uudistuneet sanoitukset muuttavat genreä. Mikäli niin yleisöllä kuin muusikoilla on aiemmasta poiketen lisäksi korkeakoulutausta (esim. kantriradion kuuntelijoista n. 36 \%:lla, ks. Veith 2001), työväenluokkaiset ja konservatiiviset arvot purevat entistä vähemmän ja saattavat vaikuttaa naiiveilta tai oudoilta. Vaikka vanhaa pidettäisiin kunniassa (mm. Lee Ann Womack), kantriin kumuloituu väistämättä uutta materiaalia. Painavin muutoksen syy löytynee silti yleisön kukkaroista. Abercombien (1996: 45) mukaan eräs tärkeä genren muuttumiseen vaikuttava tekijä on taloudellisen edun etsintä uusien yleisöjen toivossa. Kantri on tutkimusten mukaan 18-54-vuotiaiden musiikkia (ks. esim. MRI 2000), mutta esimerkiksi nuorten ostovoimaa ei enää aliarvioida Nashvillessäkään. Kuusitoistavuotias neitonen ei luultavasti osta perinteistä kantria alkoholismiin liitetyn George Jonesin laulamana, saati sitten katsele isoisänsä ikäistä elämän koulimaa miestä videolta tai dvd:ltä. Luultavammin hän haluaa haaveilla komeista nuorista miehistä, ja tähän tarpeeseen musiikkiteollisuus pyrkii vastaamaan. Muun muassa näiden syiden pohjalta syntyy monenlaista yleisöä, jotka hakevat musiikiltaan eri asioita ja myös hakevat musiikkinsa eri paikoista.

\title{
Kantriradio
}

\author{
They all say "Not Guilty!" \\ But the evidence will show \\ That murder was committed \\ Down on music row
}

$\mathrm{C} \& \mathrm{~W}$ on epäilemättä maailman amerikkalaisin populaarimusiikin laji. Vaikka ystäviä löytyy muistakin maista, kantri on selvästi suosituinta juuri USA:ssa, jossa sillä on ns. valmis asiakaspohja. C\&W siirtyy usein sukupolvelta toiselle. Siihen kasvetaan sisään kirkossa, konserteissa, kotona ja kapakoissa (ks. Peterson 1997). Myyntilukujaan nostaakseen Nashville ei havittelekaan muiden genrejen tapaan maailmalle, vaan panostaa mieluummin kotimaan markkinoille. Syyksi on mainittu mm. se, etteivät ulkomailta saadut tulot lisäisi voittoja merkittävästi. Kansainvälisen aseman saa- 
vuttaneista tähdistä (esim. Shania Twain, Dixie Chicks) huolimatta Universal, BMG, EMI ja muut Nashvillen levy-yhtiöt ovat perinteisesti keskittyneet kantriin ja jättäneet muut musiikkilajit ja globaalit markkinat muiden osastojensa harteille (New York, Los Angeles). Yhdysvalloissa C\&W:illä on käytössään useita televisiokanavia (CMT, GAC, TNT), kaupallisia Internet-sivustoja ja runsaslevikkinen musiikkilehdistö, mutta eniten myyntiä vauhdittaa radio. Sitä syytetäänkin sumeilematta $C \& W: n$ nykytilasta ja tietynlaisen musiikin suosimisesta.

Kantrimusiikkia soittavia radioasemia on Yhdysvalloissa kaikista radioformaateista (asemat, jotka soittavat vain yhden tyylilajin musiikkia) ylivoimaisesti eniten, peräti $2218 \mathrm{kpl} \mathrm{eli} 16 \%$ (RT 2002). Vertailun vuoksi mainittakoon, että uutiskanavia on noin 1100 ja seuraavaksi suurin musiikkigenre, Adult Contemporary, jää samoihin lukuihin (IO 2002). Radio on kiistatta merkittävin kantriäänitteiden menekkiä ja tunnettuutta edistävä media, kuulijoita on n. 40 miljoonaa (MRI 2000). Monet musiikkiliikkeet kieltäytyvät edes ottamasta myyntiin levyjä, joita ei ole soitettu radiossa. Vuonna 2001 kantrikanavat pitivät ensimmäistä tai toista sijaa 27:ssä koko Yhdysvaltain sadasta huippumarkkina-alueesta, joita ovat Etelän suurkaupunkien lisäksi mm. Akron, Baltimore, Denver, Indianapolis, Seattle, Toledo ja Tuscon (IO 2002). Samalla kun musiikkiteollisuus suitsuttaa kantrin suosion ja kantriasemien kasvua - Kenny Chesney, Brooks \& Dunn ja Lonestar soivat myös kantriradion ulkopuolella - yleisö miettii, miksi kantri on alkanut kuulostaa popilta ja miksi aalloilta puuttuu niin useita pitkän uran tehneitä kantriartisteja kuin innovatiivisia live-uutuuksiakin. Myös kappaleiden heikkoa vaihtuvuutta kritisoidaan. Yleisön mielestä kantriradion kantri koostuu muutaman supertähden hiteistä lopun ollessa jotain aivan muuta ${ }^{1}$.

Yleisön tyytymättömyys on tiedostettu. Jopa Nashvillen levy-yhtiöiden johtajien on kuultu sanoneen, etteivät he henkilökohtaisesti pidä siitä, mitä radiossa soitetaan, mutta heidän on pakko levyttää sellaista musiikkia, koska se on radion toive (Flippo 2002b). Radioasemien mukaan musiikki taas valitaan lähinnä mainostajien toiveiden pohjalta. Nämä puolestaan uskovat, että tietynlainen musiikki on yleisön toive ja vaatimus. Muusikot taas uskovat, että perinteinen kantri palaa vielä muodossa tai toisessa, mutta siihen saakka leipä on ansaittava ajan hengen mukaisesti ${ }^{2}$. Oli miten oli, jos yleisö kaikkoaa radiokanavilta, katoavat myös mainostajat ja mainostulot, ja asemat joutuvat lopettamaan toimintansa. Mainostettavien tuotteiden ja "oheismusiikin" valtavan markkina-arvon takia kuuntelijoista ja heidän toiveistaan tehdään tarkkoja tutkimuksia. Näiden yleisötutkimusten perimmäinen tarkoitus on helpottaa mainostajia ${ }^{3}$ löytämään juuri oikea radioasema ja kohderyhmä. Radioasemat puolestaan soveltavat niitä kontrolloidessaan ohjelmiensa sisältöä ja soitettavaa musiikkia. Tutkimusyksiköt tekevät tulosten pohjalta usein suoraan suosituksia radioasemille ja näin (tahattomasti) samalla koko musiikkiteollisuudelle. 


\title{
Kuuntelijoiden mielimusiikkia?
}

\author{
The almighty dollar \\ And the lust for worldwide fame \\ Slowly killed tradition \\ And for that, someone should hang ("Ah, you tell 'em Alan")
}

Vaikka kantrin kokonaisyleisön tiedetään koostuvan suhteellisen tasapuolisesti sekä miehistä että naisista (ks. esim. MRI 2000), naiset ovat C\&W-radiokanavien suurin kuuntelijaryhmä. Siksi kuuntelijatutkimuksia tehdään usein juuri naisten joukossa. Esimerkkinä näistä tutkimuksista mainittakoon vuoden 2001 Joint Communicationin (JC) tutkimus (WWW 2002) jossa haastateltiin n. 1060 naispuolista, 18-54-vuotiasta C\&W-radioformaatin kuuntelijaa. Vaikka otos on melko rajallinen, tulosten ja itse tutkimuksen tarkastelu antaa arvokasta tietoa kantrin kehityssuunnasta. JC:n tutkimuksen mukaan kantria kuuntelevista naisista suurin osa on työelämässä ja kuuntelee radiota pääasiassa työmatkoilla tai kotona, töissä sitä kuuntelee n. 46 \%. Naisista $85 \%$ valitsee kanavan paljon musiikin perusteella - luku on huomattavasti muita formaatteja korkeampi. Jos laulut eivät määrästään huolimatta miellytä korvaa, puolet naisista vaihtaa kanavaa. Ironista kyllä, myös liika mainostaminen ajaa naiset pois kanavilta (74 \%). Muiden formaattien kuuntelijoiden tavoin myös kantrin naiskuuntelijat pitävät lapsiaan etusijalla kanavaa valittaessa - sisällön pitää sopia myös lasten korville. Tutkimuksen "kantrinaiset" poikkesivat muiden formaattien (mm. AOR, klassinen, kristillinen, pop ja rock) kuulijoista siten, että he olivat optimisteja ja uskoivat näitä enemmän amerikkalaiseen unelmaan: he voisivat saavuttaa haluamansa, jos vain tekisivät töitä sen eteen.

Haastattelututkimuksen perusteella radiokanaville lähetetyssä yhteenvedossa avainsanoja ovat naisten työssäkäynti ja ajankäyttö, stressaantuneisuus, lapsiystävällisyys ja oikeat laulut. Koska naiset kuuntelivat radiota pääasiassa autossaan ja kotonaan, ja kokivat itsensä elämässään muiden formaattien kuuntelijoita rasittuneemmiksi, asemia kehotettiin suoraan olemaan haaskaamatta kuuntelijoiden kallista aikaa, pysymään puhuttaessa asiassa ja soittamaan naisten lempimusiikkia: kaikenlainen loukkaava aines ja liika mainostaminen saisivat jäädä pois. Musiikin tulisi olla rentouttavaa ja viihteellistä ja esimerkiksi kirosanoja olisi syytä välttää. Nämä asemille annetut "ohjeet" peilaavat melko suoraan nykyisen C\&W-genren olemusta. Juuri sellaista musiikkia useimmat kanavat soittavat - tasaista, loukkaamatonta, letkeää, amerikkalaiseen unelmaan uskovaa ja päiväunien siivittämää - kauniiden naisten ja komeiden miesten esittäminä. Naiset kun haluavat tutkimusten mukaan radion avulla paeta hetkeksi todellisuutta tai tehdä asioita, joita eivät oikeassa elämässään tekisi. JC:n tutkimat naiset myös määrittelivät itsensä poliittisesti enemmän liberaaleiksi (40\%) kuin konservatiiveiksi (32\%). Heille ja heidän perheilleen osa perinteisen kantrin arvoista ja synkästäkin ajatusmaailmasta (esim. konservatiiviset sosiaaliset roolit, ihmis- 
suhdevaikeudet, köyhyys tai kuolema) saattaa siis olla jopa luotaantyöntävä.

Vaikka genre ei ole taloudellisten tekijöiden tuote, hyvät talousnäkymät saattavat olla genren jatkuvuuden tae (Neale 1980: 51-52). Voisiko siis varovaisesti ajatella, että Nashvillen musiikintekijät ovat alkaneet pelata varman päälle ja tehdä kappaleita, jotka eivät loukkaa ketään, joissa puhutaan naisista ja heidän unelmistaan, ja jotka artistit ja tuottajat varmasti valitsevat levyilleen ollakseen ärsyttämättä mainostajia ja varmistaakseen soittoaikansa radiossa? Miehille tehtailtaisiin vastapainoksi näennäisesti räväkämpää, rock-tyylistä ja maskuliinisia arvoja (mm. itsemääräämisoikeus, alkoholi, autoilu) korostavaa musiikkia. Niin tai näin, genren ja median vuorovaikutus voidaan kantrissa selvästi katsoa yhdeksi genren muovautumisen syyksi. Formaattiperiaatteen yleistyessä valinnanvapaus lienee rajallinen myös muissa genreissä ympäri maailmaa. Kantrissa tilanne on kuitenkin hullunkurinen, sillä vaikka levy-yhtiöt syyttävät radiota siitä, ettei se huomioi heidän materiaaliaan tarpeeksi laajasti, ne omistavat itse suuren osan kantria soittavista radioasemista.

Radion ja levy-yhtiöiden puristuksessa vaihtoehtoisen ja perinteisen kantrin kuulijat löytävät omat suosikkinsa muutamaa poikkeusta lukuun ottamatta korkeintaan pienten, Nashvillen ulkopuolisten levy-yhtiöiden levyiltä tai omakustanteilta ja harvoilta Real Country tai Americana-asemilta. Tällaisen kantrin pelastus saattaa olla esimerkiksi webteknologia ja se, että kuka tahansa voi kuunnella mitä tahansa Internetin kautta. Esimerkiksi JC:n tutkimista naiskuuntelijoista 59 \%:1la oli kotonaan Internet-yhteys, jota he myös käyttivät (WWW 2002). On silti selvä, että suuren yleisön on vaikea kiinnostua jostakin asiasta, jos se ei saa tietoa sen olemassaolosta - ei näe, ei kuule, ei koe. Jos perinteiseen kantriin usein liitetyt stereotypiat luovat lisäksi kuvaa sovinistisesta, sopimattomasta ja junttimaisesta ikäloppujen miesten musiikista, ei kukaan siitä loppujen lopuksi halua mitään tietääkään. Radio jää siis osalle yleisöstä ainoaksi musiikkilähteeksi, varsinkin jos levyjen hinnat hipovat ennätyslukemia.

\section{Tuomio}

But someone killed country music

Cut out its heart and soul

They got away with murder

Down on music row

McQuailin (1987: 200) mukaan genreä voidaan pitää kätevänä työkaluna, jonka avulla mikä tahansa media voi tuottaa materiaalia tehokkaasti ja pitää tuotantonsa asiakaskuntansa odotuksia vastaavana. Hodge \& Kress (1988: 7) myötäilevät tätä todetessaan, että genre myös kontrolloi tekstin tuottajien käytöstä ja potentiaalisten kuluttajien odotuksia. Mediagenrejen voidaan näin sanoa kehittävän, rajaavan ja oikeuttavan tiettyjä asioita, kysymyksiä ja mieltymyksiä (Chandler 1997). Genre ohjaa vas- 
taanottajaansa. Tekstit asettavat lukijan tiettyyn asemaan, josta hänen tulee tulkita tekstiä "oikein". Tuo asema voi olla kirjoittajan rakentama: ideaalinen lukija tai kuulija (ks. esim. Kress 1988: 107). Tämän ideaalisen lukijan asenteet, sosiaalinen luokka, ikä, sukupuoli ja etninen tausta ovat hyvin selvillä (Chandler 1997). Nashville näyttää kuitenkin erityisesti perinteisen kantrin ystävien mielestä rikkoneen tekijän ja kuulijan välistä sopimusta julkaisemalla musiikkia, joka ei markkinointitutkimuksista ja myyntiluvuista huolimatta vastaa kaikkien odotuksia - traditio on pelkkää sanahelinää. Autoradion suosikit eivät toimikaan kotona levylautasella, jonne mahtuisi myös radioformaattia (3.20-3.30 min) pidempiä ja kenties sanoituksellisesti syvällisempiä, kokeilevampia kappaleita.

Kun Nashvillessä markkinointi-tutkimusten pohjalta 1980-luvulla todettiin, että kantriyleisö, erityisesti naiset, keskittää ostovoimansa nuoriin valovoimaisiin tähtiin, levyteollisuus ryhtyi toimenpiteisiin. Columbia Records kieltäytyi jatkamasta Johnny Cashin levytyssopimusta, koska taiteilija oli heidän mielestään liian vanha. Saman kohtalon ovat myöhemmin kokeneet myös Waylon Jennings, Merle Haggard ja Dolly Parton (Flippo 2002a). Nashville tuntui unohtaneen, että mediateoreettinen kommunikaation perusmalli koostuu kolmesta osatekijästä: tekstistä, sen tuottajista ja sen yleisöstä (ks. Fairclough 1995), eivätkä tekstien tuottajat ole niiden ainoita käyttäjiä. Yleisöllä on omat tarpeensa, toiveensa ja tulkintansa ja joskus tuottajien ja yleisön näkemykset käyvät ristiin (Chandler 1997). Niinpä 1980- ja 1990-lukujen taitteessa levyjen myyntiluvut olivat ennätysalhaisia, mutta 90-luvulla ne piristyivät uustraditionalistien ja Garth Brooksin ${ }^{4}$ ansiosta. Genre uudistui osittain perinteiden ehdoilla. Nykyään vetojuhtina toimivat Straitin ja Jacksonin kaltaiset artistit ja sellaiset megatähdet kuin Tim McGraw. Myös vanhat, vanhaan tukeutuvat tai vaihtoehtoiset levyttävät omilla tahoillaan, pienemmän markkinointikoneiston tuella.

Perinteisesti kriitikot ovat pitäneet genren sisäisiä tekstejä (tuotettuja tekstejä) vähempiarvoisina kuin niitä tekstejä, jotka on tuotettu genren ulkopuolella tai rajoilla. Monet puhtauden kannattajat vaalivat romantiikan aikakaudella syntynyttä ideologiaa "kirjailijan" aitoudesta ja näkemyksestä ja painottavat omintakeista tyyliä ja taiteellista itseilmaisua. (Chandler 1997.) Tämä näkyy myös tavallisen yleisön asenteissa, erityisesti rock-musiikissa, jonka olennaisia osia aitous ja kapina ovat, mutta myös $\mathrm{C} \& W$-piireissä, joissa tekstien suorasukaisuuteen on totuttu. Vaikka $\mathrm{C} \& \mathrm{~W}$ on kaupallista viihdettä, perinteisen kantrin kannattajat voisivat hyvin olla romantiikan edustajia. Toinen puoli kantrin yleisöstä taas ymmärtää $\mathrm{C} \& \mathrm{~W}: n$ markkina-arvon ja myöntää joidenkin artistien olevan tuotteita. CMT:n (DP 2002) vuoden 2002 lopulla teettämän Internet-kyselyn mukaan 49 \% vastanneista uskoi levy-yhtiöiden maksimoivan vuoden 2003 tulonsa, mikäli ne panostaisivat jo olemassa olevien artistien urakehitykseen entistä enemmän. Uusien lahjakkuuksien varaan laski vain $13 \%$. Kysymyksenasettelu sinällään osoittaa avointa kaupallisuuden hyväksymistä karkottaen kuulijat, jotka pitävät "aidosta" tuotteesta. 
Nealen (1980: 48) mukaan genre on paikka, jossa vanha ja uusi kohtaavat. Uusi on hänen mukaansa genren olemassaolon ehdoton edellytys, sillä pelkkä vanhan toistaminen ei pitemmän päälle miellyttäisi yleisöä. Kantrissa Tudorin (1974) mainitsemat eriytyminen ja uusiutuminen ovat Nashvillen tiukassa kontrollissa. Uusiutumista ei tapahdu, koska samat ammattilaismuusikot muotoilevat laulunsa samaan kaupalliseen, turvalliseen muottiin ja tekstit jaetaan samoja turvallisia kanavia pitkin, toisiaan kovasti muistuttavien uusien artistien esittäminä. Vanhat artistit hylätään mm. ulkomusiikillisten seikkojen takia, eivätkä uudet omaleimaiset lahjakkuudet koskaan pääse kustantajia pidemmälle liian omaperäisyytensä vuoksi. Valtavirrasta ja genren kehdosta poikkeamisen hintana on siis joko pienen piirin suosio tai unhola. Jos joku LeAnn Rimesin tapaan julistautuu puhtaasti poppariksi, kantriyleisön selvästä pettymyksestä huolimatta Nashville ei päästä taiteilijaa ja hänen uutta tuotantoaan menemään, vaan kohtelee tätä edelleen kantrina - näin eriytyminen estetään ja kantrikanavat soittavat Coyote Ugly -soundtrackia ja Shania Twainin UP!-albumin C\&W-versiota. Hintana on musiikin puuroutuminen ja onttous. Vaikka osa uudesta yleisöstä kiinnostuisi popin houkuttamana myös perinteisemmästä kantrista, se voi pettyä karvaasti todettuaan kantrin olevankin jotain muuta kuin mitä annettiin ymmärtää (poptyyliin livertävä Mindy McCready vs. perinteisen paatoksellinen Lorrie Morgan). Artistin sen sijaan on valittava puolensa, vain harvat menestyvät monissa genreissä yhtä aikaa.

Genren kiertoliike ja muutos voidaan nähdä yhteiskunnallisia, poliittisia ja taloudellisia oloja peilaavana. Genren määritelmät ovat aina sidoksissa ympäröivään aikaan ja historiaan. (Chandler 1997.) On selvää, että C\&W on arvokas osa amerikkalaista kulttuuriperintöä ja ajankuvaa, eikä se Murder on the Music Row -kappaleen viestistä huolimatta ole kuollut, vaan elää ympäröivän yhteiskunnan mukana. Vuonna 2001 kantrialbumien osuus kaikista USA:ssa myydyistä albumeista oli kunnioitettavat 10.5 \% eli noin 68.5 miljoonaa kappaletta (IO 2002), eikä tuoreiden kasvojen, cross-over hittien ja ehkä jopa isänmaallisten laulujen (vrt. vuoden 2001 syyskuun terrori-isku, talouslama jne.) osuutta liene syytä vähätellä. Genre toimii kantrissakin kenttänä, jossa tuottajat ja yleisö keskustelevat yhteisistä arvoista ja uskomuksista ja säilyttävät näin järjestyksen yhteiskunnassa myös muutoksen aikana (ks. Chandler 1997). C\&W on tuntojen tulkki ja hakee identiteettiään uudenlaisessa, mutta edelleen suhteellisen konservatiivisessa Amerikassa kaikilla diskurssin osa-alueilla.

Flippo (2002c) on punaisen ja sinisen kantrin lisäksi määritellyt genreen myös purppuran suuntauksen. Sitä edustaa mm. O Brother, Where Are Thou -soundtrack. Purppurassa vanhaa ja uutta on sekoitettu tavalla, joka tuntuu miellyttävän niin uutta kuin vanhaakin yleisöä. Purppura on todiste siitä, että genre takaa oman olemassaolonsa toimimalla inspiraationa musiikintekijälle, liian kontrollin ja tuotteistamisen taas tukahduttaessa muutoksen ja kehityksen. Petersonin (1997: 67) mukaan aitous perustuu uudistumiskykyyn ja Flippon (2002b) mielestä monen kantriartistin menestys 
pohjautuu taitoon löytää menneisyydestä uusia keinoja, joiden avulla tarkastella nykyisyyttä. Mikäli genren halutaan pysyvän elinvoimaisena, musiikillinen vapaus ja eriytyminen, myös perinteet, sallittakoon- varsinkin jos lajityyppi alun perin on rakentunut juuri individualismille ja elämän moninaisuuden rehelliselle kuvaamiselle.

\section{Viitteet}

1 Ks. esim. http://www.takecountryback.com/ main.htm.

2 Esim. Brooksille ja Straitille lauluja tehnyt Kim Williams (2000).

3 Kantrikanavilla mm. Bud Light, Coors Light, Dr. Pepper, Chevrolet, Dunlop, Ford Motor, Jim Beam, Slim Fast ja Wrangler.
4 Brooks on myynyt n. 104 miljoonaa levyä ja ollut seitsemän kertaa pop-listojen ykköspaikalla - useammin kuin kukaan muu artisti missään genressä (IO 2002). Hänen suosionsa perustunee taitoon yhdistää kantrin kristilliset arvot pop- ja rockmusiikkiin.

\section{Lähteet}

\section{AINEISTO}

Shell, Larry \& Cordle, Larry (1999) Murder on the Music Row. Albumilla Strait, George (2000) Latest Greatest Straitest Hits. MCA: Nashville. Sanat saatavilla Internet-osoitteesta http://www.coquetshack.com/lyrics/Lyrics_M/ Murder_On_Music_Row_1637. htm (tarkistettu 1.12.2002).

\section{HAASTATTELUT}

Williams, Kim (2000) Kirjoittajan tekemä sähköpostihaastattelu 11.4.2000.

\section{INTERNET-LÄHTEET}

Chandler, Daniel (1997) "An Introduction to Genre Theory". http://www.aber.ac.uk/media/ Documents/intgenre/intgenre1.html (tarkistettu 17.11.2002).

DP (2002) CMT Daily Poll 12/16/02. www.cmt.com (tarkistettu 16.12.2002).

Flippo, Chet (2002a) "NASHVILLE SKYLINE: Dwight Is Still Pretty Cool”. http:// www.cmt.com/news/display/1458914.jhtml (tarkistettu 27.11.2002).

Flippo, Chet (2002b) 'NASHVILLE SKYLINE: Future of the Music Is Here Today". http:/ /www.cmt.com/news/display/1454601.jhtml (tarkistettu 30.5.2002).

Flippo, Chet (2002c) "NASHVILLE SKYLINE: Red Country vs. Blue Country". http:// www.cmt.com/news/display/1458053.jhtml (tarkistettu 10.10.2002).

IO (2002) Country Music Industry Overview 2002. http://www.cmaworld.com/marketing/ resource_industryoverview.asp (tarkistettu 1.12.2002).

MRI (2000) MRI Country Listener Analysis 2000. http://www.cmaworld.com/marketing/ default.asp (tarkistettu 1.5.2001). 
RT (2001) 2001 Radio Today. How America Listens to Radio. http://www.arbitron.com/ ad_agencies/ratings_reports_freestudies.htm\#radio (tarkistettu 1.12.2002).

Veith, Gene Edward (2001) "Country Music Culture Wars. Values and Symbols of Nashville, Tenn". http://www.milligan.edu/communications/Library/Articles1/CountryWars. htm (tarkistettu 1.5.2001).

WWW (2002) What Women Want from Country Radio. http://www.arbitron.com/ad_ agencies/ratings_reports_freestudies.htm\#radiowww (tarkistettu 1.12.2002).

\section{PAINETUT LÄHTEET}

Abercrombie, Nicholas (1996) Television and Society. Cambridge: Polity Press.

Fairclough, Norman (1995) Media Discourse. London, New York, Sydney, Auckland: Edward Arnold.

Gledhill, Christine (1985) "Genre". The Cinema Book. Ed. Pam Cook. London: British Film Institute.

Hodge, Robert \& Gunther Kress (1988) Social Semiotics. Cambridge: Polity Press.

Kalliokoski, Jyrki (1996) "Johdanto". Teksti ja ideologia. Kieli ja valta julkisessa kielenkäytössä. Toim. J. Kalliokoski. Helsinki: Helsingin yliopiston suomen kielen laitos. Ss. 8-36.

Kress, Gunther (1988) Communication and Culture: An Introduction. Kensington, NSW: New South Wales University Press.

McQuail, Denis (1987) Mass Communication Theory: An Introduction. London: Sage.

Neal, Jocelyn (1998) "The Metric Makings of a Country Hit". Reading Country Music Steel Guitars, Opry Stars and Honky-Tonk Bars. Ed. Cecilia Tichi. Duke University Press: London. Ss. 322-337.

Neale, Stephen (1980) Genre. London: British Film Institute.

Peterson, R. A. (1997) Creating Country Music. Fabricating Authenticity. Chicago \& London: University of Chicago Press.

Tudor, Andrew (1974) Image and Influence: Studies in the Sociology of Film. London: George Allen \& Unwin.

Walser, Robert (1993) Running with the Devil. Power, Gender, and Madness in Heavy Metal Music. Hanover \& London: Wesleyan University Press \& University Press of New England. 